\title{
Knowledge attitude and practices towards chronic kidney disease among type-2 diabetic patients in Bangladesh
}

\author{
Atitude e práticas em relação à doença renal crônica entre \\ pacientes diabéticos tipo-2 em Bangladesh
}

\section{Rajib Mondal' 1 (1) Rani Baroi Ritu ${ }^{2}$ (1) Md. Shamsur Rahman ${ }^{3}$ (1) Rajib Chandra Sarker ${ }^{4}$ (1) Palash Chandra Banik 5 (1)}

\begin{abstract}
${ }^{1}$ Corresponding author. Department of Public Health, Hamdard University Bangladesh (HUB) (Munshiganj), Center for Noncommunicable diseases Prevention Control Rehabilitation \& Research (CeNoR) (Dhaka). Bangladesh, Ásia. rajibmondaluday@gmail.com ${ }^{2.4} \mathrm{Center}$ for Noncommunicable diseases Prevention Control Rehabilitation \& Research (CeNoR) (Dhaka). Bangladesh, Ásia. rb.ritu98@gmail.com, rousseau.physio@gmail.com, thercs69@gmail.com ${ }^{5}$ Center for Noncommunicable diseases Prevention Control Rehabilitation \& Research (CeNoR) (Dhaka), Department of Noncommunicable Diseases, Bangladesh University of Health Sciences (BUHS) (Dhaka). Bangladesh, Ásia. palashcbanik@gmail.com
\end{abstract}

\begin{abstract}
INTRODUCTION: Proper knowledge, attitude, and practices (KAP) towards chronic kidney disease (CKD) among type2 diabetes mellitus (T2DM) patients is very important to reduce the disease burden. However, the information about KAP towards CKD among Bangladeshi T2DM patients is unknown, based on the available literature to date. OBJECTIVES: We aimed to assess the KAP towards CKD among T2DM patients who attended a selected hospital in Dhaka city. METHODS AND MATERIALS: In this cross-sectional study, we conveniently selected Aalok hospital and 224 T2DM patients who attended the outdoors. We excluded the already developed CKD patients and aged over 70 years. We adopted a questionnaire from a validated instrument consisted of a 10 item knowledge, 8 items attitude, and 7 items practice domains towards CKD (total 25 items). Face-to-face interviews collected data. Descriptive and comparative (Independent Sample t-tests and One-way ANOVA tests) statistics were used for data analysis where appropriate. RESULTS: Women respondents were higher (69.6\%). The mean age of the respondents was $49.8 \pm 11.3$ years. Most of them had an average level of knowledge (69.6\%) and attitude (60.7\%). The majority also reported good hypothetical practices in general if they would find out to have CKD. Knowledge was significantly associated $(p<0.05)$ with sex, level of education, occupation, and income, whereas attitude was with sex, occupation, and income. CONCLUSION: T2DM patients of our study mainly reported an average level of knowledge and attitude and good hypothetical practices in general towards CKD. Proper health awareness programs are needed to increase the KAP towards CKD among T2DM patients in Bangladesh.
\end{abstract}

KEYWORDS: Attitude. Bangladesh. Chronic kidney disease. Knowledge. Practices. Type-2 diabetes mellitus.
RESUMO | INTRODUÇÃO: Ter conhecimento, atitude e práticas adequadas (CAP) em relação à doença renal crônica (DRC) entre pacientes com diabetes mellitus tipo 2 (DM2) é muito importante para reduzir a carga da doença. No entanto, a informação sobre KAP em relação à DRC entre pacientes com DM2 de Bangladesh é desconhecida, com base na literatura disponível até a data. OBJETIVOS: Nosso objetivo foi avaliar o KAP em relação à DRC entre pacientes com DM2 atendidos em um hospital selecionado na cidade de Dhaka. MÉTODOS E MATERIAIS: Neste estudo transversal, selecionamos convenientemente o hospital Aalok e também seus 224 pacientes com DM2 que compareceram ao exterior. Excluímos os pacientes com DRC já desenvolvida e com idade superior a 70 anos. Adotamos um questionário de um instrumento validado composto por 10 itens de conhecimento, 8 itens de atitude e 7 itens de domínios de prática em relação à DRC (total de 25 itens). Os dados foram coletados por meio de entrevistas presenciais. As estatísticas descritivas e comparativas (testes $t$ de amostra independente e ANOVA de uma via) foram usadas para a análise de dados quando apropriado. RESULTADOS: As mulheres entrevistadas foram mais altas $(69,6 \%)$. A média de idade dos entrevistados foi de $49,8 \pm 11,3$ anos. A maioria deles tinha nível médio de conhecimento $(69,6 \%)$ e atitude $(60,7 \%)$. A maioria também relatou boas práticas hipotéticas em geral, caso descobrissem que têm CKD. 0 conhecimento associou-se significativamente $(p<0,05)$ com sexo, escolaridade, ocupação e renda, enquanto a atitude esteve com sexo, ocupação e renda. CONCLUSÃO: Os pacientes Com DM2 de nosso estudo relataram, em sua maioria, nível médio de conhecimento e atitude, e boas práticas hipotéticas em geral em relação à DRC. Programas adequados de conscientização sobre saúde são necessários para aumentar o CAP em relação à DRC entre pacientes com DM2 em Bangladesh.

PALAVRAS-CHAVE: Atitude. Bangladesh. Doença renal crônica. Conhecimento. Práticas. Diabetes Mellitus tipo 2. 


\section{Introduction}

Chronic kidney disease (CKD) is one of the major silent killers worldwide, leading to a significant global public health burden. Overall, 5-10 million global deaths are occurring annually due to kidney diseases. ${ }^{1}$ Around 8-16\% of people worldwide live with $C K D^{2-3}$, and it is $19-26 \%$ in Bangladesh. ${ }^{4-5}$ However, the global estimation of kidney diseases can be considered an iceberg as such numbers probably underestimate the true burden due to the limited epidemiological data, resulting from lack of awareness and poor access to the laboratory services..$^{1}$ Moreover, CKD is tremendously higher among patients with type2 diabetes mellitus (T2DM), regarded as the most common cause..$^{2,6-7}$ It also is immensely prevalent (13.9-63.5\%) among Bangladeshi T2DM patients. ${ }^{8-9}$

It is very important to have proper knowledge, attitude, and practices (KAP) towards CKD among patients with diabetes mellitus (DM) to reduce the disease burden. ${ }^{10}$ However, an extreme dearth of the study explored the KAP towards CKD among T2DM patients without CKD. In Jordan, the KAP towards prevention and early detection of CKD was evaluated among patients with either DM or hypertension, and it was reported as a good level of knowledge (mean \pm SD percentage $80.24 \pm 10.4$ ) and attitude (mean \pm SD percentage $78.7 \pm 8.1$ ), but relatively poor practice (mean \pm SD percentage $64.9 \pm 10.6$ ) among them. ${ }^{11} \mathrm{~A}$ similar study in Australia was conducted to assess the knowledge about kidney disease among patients with T2DM and other diseases, and a low level of expertise (average of 20\%) was reported. ${ }^{12}$ A group of T2DM patients and/or hypertension inclusive 26\% CKD in Ethiopia reported $63.5 \%$ and $36.5 \%$ of them had poor and average knowledge, respectively, and $41.3 \%$ with a positive attitude. $\frac{13}{}$ However, to our best searching knowledge based on the available literature till the date, there is no study assessing the KAP towards CKD among specifically the T2DM patients without CKD in Bangladesh.

Bangladesh is an overpopulated country with 161 million people. $\frac{14}{} \mathrm{~A}$ remarkable number of them are suffering from diabetes, accounting for around 10\% of its population. $\frac{15}{15}$ This large number of DM patients is at risk of developing CKD, considering the strong interaction between diabetes and CKD. ${ }^{2,6-7}$ Therefore, it is highly important to explore the KAP towards
CKD among them, which is unknown. We aimed to assess the level of KAP towards CKD among T2DM patients who attended a selected private hospital in Dhaka city. The findings of this study will help the policymakers design and implement the necessary and appropriate strategies to increase the awareness about CKD among this high-risk population to lower the future disease burden.

\section{Methods}

\section{Study design, setting, and population}

This cross-sectional study was conducted in 2019 among 224 T2DM patients who attended the outdoor diabetic care settings of Aalok Healthcare Ltd. (branch no. 2). The Aalok Healthcare Ltd. is a general hospital setup that belongs to the private sector situated in the Mirpur area of Dhaka (the north zone of City Corporation), the capital city of Bangladesh. It has its own diabetic care setup with several expert diabetologists. The adult diabetic patients aged not above 70 years, and those who had diabetes for at least one year and no history of already diagnosed CKD, were enrolled in this study.

\section{Sampling technique}

The Aalok Healthcare was selected conveniently. Moreover, the diabetic patients were also enrolled following the same convenient sampling technique among those who visited the diabetic care outdoors during the data collection period. Although the conveniently selected subjects are not inferential enough to represent the whole study population, several potential issues stimulated us to design this sampling such as, especially, this hospital does not have its own registered diabetic patients and record book with contact details, we had to rely on outdoor settings for data collection, few patients were in time constraint, and also a low-resourced study setting.

\section{Data collection instrument and technique}

We adopted a structured questionnaire with the necessary modifications from the KAP Survey Instruments developed by Stanifer et al. to assess kidney disease knowledge, attitude, and practices. 
They validated their instrument in the Comprehensive Kidney Disease Assessment for Risk factors, epidemiology, Knowledge, and Attitudes (CKD Afrika) Study. $\frac{16}{1}$ Our study questionnaire was comprised of socio-demographic variables (such as sex, age, education, occupation, income, and area of living) and variables related to the knowledge, attitude, and practices towards CKD. The instrument was occupied with 25 items divided into three specific domains- knowledge, attitude, and practice, whereas 10 items were in the knowledge domain, 8 were in the attitude domain, and the remaining 7 were in the practice domain. The knowledge domain consisted of the information related to the etiologies, diagnosis, and treatment of CKD and the normal function of the kidneys. Its items were measured with a four-point categorical response scale ('Yes,' 'No,' 'Don't know,' and 'Unsure'). The attitude domain was consisted of the information related to the learning and health concerns, economic concerns, and social impacts. Its items were measured with a dichotomous response scale ('Yes' and 'No'). The practice domain was consisted of hypothetical practices related to healthseeking behaviors. Its items were measured with a four-point Likert-based scale ('Very unlikely,' 'Unlikely,' 'Likely,' and 'Very likely'). The data were collected by a group of well-trained data collectors and the researcher selves, using a face-to-face interview process. Patients were recognized as non-CKD (selfreported) based on the 'no' or 'unknown' response when asked whether they had a history of previously diagnosed CKD by any doctor. $\frac{16}{}$

\section{Data processing and statistical procedure}

We used SPSS software (IBM Corp. Released 2013. IBM SPSS Statistics for Windows, Version 21.0. Armonk, NY: IBM Corp.) to process and analyze the data. Before going to the statistical procedures, we scored all of the variables of knowledge and attitude domains.

\section{Scoring of the variables}

For the knowledge domain, a composite score (ranged: 0-10) was calculated. Each item was treated and scored as correct (1) with the response 'Yes'; or incorrect (0) with the responses 'No,' 'Don't know' and 'Unsure.' Then the sum of the 10 scored items was obtained. For the attitude domain, a composite score (ranged: 0-8) was calculated. Each item was treated and scored as positive with the response 'Yes' (1) or negative with ' $\mathrm{No}^{\prime}(0) 16$. Then the sum of the 8 scored items was obtained. And finally, we categorized the level of knowledge and attitude as poor, average, and good. The poor, average, and good levels were determined when the knowledge and attitude scores were $<$ Mean $\pm 1 S D$, within the range of Mean $\pm 1 S D$, and $>$ Mean +1 SD respectively.

\section{Statistical procedure}

Descriptive statistics were done for the sociodemographic section and knowledge, attitude, and practice domains and expressed as a number, percentage (with confidence interval), mean, standard deviation (SD), and interquartile range (IQR) where appropriate. Comparative statistics such as Independent Sample t-tests and One-way ANOVA tests were done to see the relationships between the socio-demographic factors and the knowledge and attitude domains. The level of statistically significant difference was considered when the $p$-value was $<0.05$ in these relationships. A Bland-Altman Plot was produced showing the difference against the mean for these scores and corresponding 95\% confidence interval superimposed on the plot to demonstrate the agreement between the knowledge and attitude domain scores.

\section{Ethical considerations}

The study protocol was approved by the Ethical Review Committee (ERC) of the Center for Noncommunicable diseases Prevention Control Rehabilitation \& Research (Identification no. CeNoR/EA/1902). Permission for data collection was taken from the authority of Aalok Healthcare Ltd. Both verbal and written informed consents were taken from all of the respondents before data collection.

\section{Results}

Women respondents were higher (69.6\%). The mean \pm SD age of the respondents was $49.8 \pm 11.3$ years, whereas most of them (30.4\%) were with their 50-59 years. One-third of them (33.9\%) were secondary school passed, followed by graduation and more, and so on. Most of the respondents (64.3\%) were housewives. Nearly three in every five respondents $(58.9 \%)$ had a monthly income of less than 30,000 BDT (Bangladeshi Taka). And, four in every five (80.4\%) lived in an urban area (Table 1 ). 
Table 1. Socio-demographic characteristics of the respondents $(n=224)$

\begin{tabular}{|c|c|}
\hline Characteristics & Number (\%) \\
\hline \multicolumn{2}{|l|}{ Sex } \\
\hline Men & $68(30.4)$ \\
\hline Women & $156(69.6)$ \\
\hline \multicolumn{2}{|l|}{ Age (in years) } \\
\hline Mean $\pm S D(I Q R)$ & $49.8 \pm 11.3(40-60)$ \\
\hline$<40$ & $40(17.9)$ \\
\hline $40-49$ & $56(25.0)$ \\
\hline $50-59$ & $68(30.4)$ \\
\hline$\leq 60$ & $60(26.8)$ \\
\hline \multicolumn{2}{|l|}{ Level of education } \\
\hline Illiterate & $40(17.9)$ \\
\hline Primary school pass & $36(16.1)$ \\
\hline Secondary school pass & 76 (33.9) \\
\hline Higher secondary school pass & $24(10.7)$ \\
\hline Graduation and more & $48(21.4)$ \\
\hline \multicolumn{2}{|l|}{ Occupation } \\
\hline Employee & $32(14.3)$ \\
\hline Business & $20(8.9)$ \\
\hline Day labor/farmer & $4(1.8)$ \\
\hline Housewife & $144(64.3)$ \\
\hline Others & $24(10.7)$ \\
\hline \multicolumn{2}{|l|}{ Monthly family income (in BDT) } \\
\hline Mean $\pm S D(I Q R)$ & $29,375 \pm 29,532(20,000-30,000)$ \\
\hline$<30,000$ & $132(58.9)$ \\
\hline $30,000-50,000$ & $84(37.5)$ \\
\hline$>50,000$ & $8(3.6)$ \\
\hline \multicolumn{2}{|l|}{ Area of living } \\
\hline Urban & $180(80.4)$ \\
\hline Rural & 44 (19.6) \\
\hline
\end{tabular}

In terms of knowledge about CKD among the respondents regarding the etiology, we found that most of our study population knew that CKD could be caused by high blood sugar or diabetes (75.0\%). For diagnosis of CKD, half (48.2\%) knew that a test at the hospital could only diagnose CKD. For preventive strategy, most of them (94.6\%) knew that CKD could be prevented if it is followed the advice of a medical doctor. For normal functions of kidneys, a minor of them knew that kidneys control body temperature (17.9\%) and filter waste products from the blood (26.8\%). For treatment of CKD, only $35.7 \%$ of them knew that dialysis was a form of treatment. However, the overall mean $\pm S D$ of knowledge score among them was $4.2 \pm 2.3$ out of maximum possible 10 points. And, most of them (69.6\%) had an average level of knowledge (details in Table 2 ). 
Table 2. Knowledge and attitude towards chronic kidney disease among the diabetic population in a selected hospital in Dhaka city of Bangladesh ( $\mathrm{n}=224$ )

\begin{tabular}{|c|c|}
\hline Knowledge and attitude related variables & $\begin{array}{l}\text { \% of correct responses } \\
\qquad(95 \% \mathrm{Cl})\end{array}$ \\
\hline \multicolumn{2}{|l|}{ Knowledge domain } \\
\hline \multicolumn{2}{|l|}{ Survey items } \\
\hline \multicolumn{2}{|l|}{ Etiology } \\
\hline Q1 (do you think high blood pressure can cause kidney disease?) & $42.9(36.4,49.4)$ \\
\hline Q2 (do you think high blood sugar (diabetes) can cause kidney disease?) & $75.0(69.3,80.7)$ \\
\hline Q3 (drinking alcohol can cause kidney disease?) & $58.9(52.5,65.3)$ \\
\hline \multicolumn{2}{|l|}{ Diagnosis } \\
\hline $\begin{array}{l}\text { Q4 (a person can tell if he/she has kidney disease just by the color, quality, or } \\
\text { smell of urine?) }\end{array}$ & $8.9(5.2,12.6)$ \\
\hline Q5 (kidney disease can only be diagnosed by a test at the hospital?) & $48.2(41.7,54.7)$ \\
\hline Q6 (kidney disease can be prevented if you follow the advice of a medical doctor?) & $94.6(91.6,97.6)$ \\
\hline \multicolumn{2}{|l|}{ Normal function } \\
\hline Q7 (do the kidneys control body temperature?) & $17.9(12.9,22.9)$ \\
\hline Q8 (the kidneys filter waste products from the blood?) & $26.8(21.0,32.6)$ \\
\hline \multicolumn{2}{|l|}{ Treatment } \\
\hline Q9 (dialysis is a form of treatment for kidney disease?) & $35.7(29.4,42.0)$ \\
\hline Q10 (antibiotics are a form of treatment for kidney disease?) & $12.5(8.2,16.8)$ \\
\hline Mean $\pm S D$ knowledge score (IQR) & $4.2 \pm 2.3(3.0-5.8)$ \\
\hline Converted Mean \pm SD knowledge percentage & $42 \pm 23$ \\
\hline \multicolumn{2}{|l|}{ Level of knowledge } \\
\hline Poor & $10.7(6.7,14.7)$ \\
\hline Average & $69.6(63.6,75.6)$ \\
\hline Good & $19.6(14.4,24.8)$ \\
\hline \multicolumn{2}{|l|}{ Attitudes domain (positive responses were counted) } \\
\hline \multicolumn{2}{|l|}{ Survey items } \\
\hline \multicolumn{2}{|l|}{ Learning and health concerns } \\
\hline Q1 (have you thought you may have kidney problems?) & $44.6(38.1,51.1)$ \\
\hline Q2 (do you like the idea of learning about kidney problems?) & $87.5(83.2,91.8)$ \\
\hline Q3 (. . would you be worried about your future?) & $91.1(87.4,94.8)$ \\
\hline Q6 (. . would you be worried about your chances of survival?) & $89.3(85.3,93.3)$ \\
\hline \multicolumn{2}{|l|}{ Economic concerns } \\
\hline Q5 (...would you be worried about your ability to work?) & $89.3(85.3,93.3)$ \\
\hline Q8 (do you think the cost of kidney disease would be a problem for you?) & $89.3(85.3,93.3)$ \\
\hline \multicolumn{2}{|l|}{ Social impact } \\
\hline Q4 (... would you be worried about your reputation in the community?) & $64.3(58.0,70.6)$ \\
\hline Q7 (do you think kidney disease is a problem in Dhaka?) & $98.2(96.5,100.0)$ \\
\hline Mean $\pm S D$ attitude score (IQR) & $6.5 \pm 1.4(6.0-8.0)$ \\
\hline Converted Mean $\pm S D$ attitude percentage & $81.3 \pm 17.5$ \\
\hline \multicolumn{2}{|l|}{ Level of attitude } \\
\hline Poor & $10.7(6.7,14.7)$ \\
\hline Average & $60.7(54.3,67.1)$ \\
\hline Good & $28.6(22.7,34.5)$ \\
\hline
\end{tabular}

$\mathrm{Cl}=$ confidence interval; $\mathrm{SD}=$ standard deviation; IQR= interquartile range; Poor= score $<$ Mean-1SD; Average $=$ score

within the range of Mean \pm 1 SD; Good= score $>$ Mean+1SD

In terms of attitude towards CKD among the respondents, in case of learning and health concerns, most of them reported that they would like the idea of learning about kidney problems (87.5\%) and would be worried about their future (91.1\%) as well as chances of survival (89.3\%) if they diagnosed as having CKD. Most of them reported their concern about their economic and social impacts. However, the overall mean \pm SD of attitude score among them was $6.5 \pm 1.4$ out of maximum possible 8 points. And, most of them (60.7\%) had an average level of attitude (details in Table 2). 
In terms of practice about CKD among the respondents, they were willing to seek healthcare services from various possible sources. If they found out to have CKD, most of them would be likely or very likely to seek care at a hospital or health clinic (17.9\% and $73.2 \%$, respectively) or from a medical doctor ( $14.3 \%$ and $82.1 \%$, respectively). Most of them would be likely to be contacted to care for their kidneys by technology-based services like a cell phone. However, they were not that willing to be contacted by email. Although most of them were willing to seek care from medical or clinic or doctor, few of them also would be likely or very likely to seek care from a traditional healer as well as to use traditional remedies like herbal or natural medications, and also would be likely or very likely to seek self-treatment at home (details in Table 3).

Table 3. Practice about chronic kidney disease among the diabetic population in a selected hospital in Dhaka city of Bangladesh ( $\mathrm{n}=224$ )

\begin{tabular}{|c|c|c|c|c|}
\hline \multirow[t]{2}{*}{ Practice domain } & $\begin{array}{l}\text { Very } \\
\text { unlikely }\end{array}$ & Unlikely & Likely & Very likely \\
\hline & \multicolumn{4}{|c|}{$\%(95 \% \mathrm{Cl})$} \\
\hline \multicolumn{5}{|l|}{$\begin{array}{l}\text { Q1 (If you found out that you have kidney } \\
\text { problems...) }\end{array}$} \\
\hline $\begin{array}{l}\text { a. How likely would you be to seek care from a } \\
\text { traditional healer? }\end{array}$ & $\begin{array}{c}60.7 \\
(54.3,67.1)\end{array}$ & $\begin{array}{c}21.4 \\
(16.0,26.8)\end{array}$ & $\begin{array}{c}8.9 \\
(5.2,12.6)\end{array}$ & $\begin{array}{c}8.9 \\
(5.2,12.6)\end{array}$ \\
\hline $\begin{array}{l}\text { b. How likely would you be to seek self- } \\
\text { treatment at home? }\end{array}$ & $\begin{array}{c}50.0 \\
(43.5,56.5)\end{array}$ & $\begin{array}{c}37.5 \\
(31.2,43.8)\end{array}$ & $\begin{array}{c}7.1 \\
(3.7,10.5)\end{array}$ & $\begin{array}{c}5.4 \\
(2.4,8.4)\end{array}$ \\
\hline $\begin{array}{l}\text { c. How likely would you be to seek care at a } \\
\text { hospital or health clinic? }\end{array}$ & $\begin{array}{l}5.4 \\
(2.4,8.4)\end{array}$ & $\begin{array}{l}3.6 \\
(1.2,6.0)\end{array}$ & $\begin{array}{c}17.9 \\
(12.9,22.9)\end{array}$ & $\begin{array}{c}73.2 \\
(67.4,79.0)\end{array}$ \\
\hline $\begin{array}{l}\text { d. Would you be willing to be contacted by cell } \\
\text { phone regarding care of your kidneys? }\end{array}$ & $\begin{array}{c}10.7 \\
(6.7,14.7)\end{array}$ & $\begin{array}{c}3.6 \\
(1.2,6.0)\end{array}$ & $\begin{array}{c}32.1 \\
(26.0,38.2)\end{array}$ & $\begin{array}{c}53.6 \\
(47.1,60.1)\end{array}$ \\
\hline $\begin{array}{l}\text { e. Would you be willing to be contacted by email } \\
\text { regarding care of your kidneys? }\end{array}$ & $\begin{array}{c}14.3 \\
(9.7,18.9)\end{array}$ & $\begin{array}{c}69.6 \\
(63.6,75.6)\end{array}$ & $\begin{array}{c}7.1 \\
(3.7,10.5)\end{array}$ & $\begin{array}{c}8.9 \\
(5.2,12.6)\end{array}$ \\
\hline $\begin{array}{l}\text { Q2 (How likely would you be to use herbal or } \\
\text { natural medications if you found out that you } \\
\text { have kidney disease?) }\end{array}$ & $\begin{array}{c}32.1 \\
(26.0,38.2)\end{array}$ & $\begin{array}{c}23.2 \\
(17.7,28.7)\end{array}$ & $\begin{array}{c}30.4 \\
(24.4,36.4)\end{array}$ & $\begin{array}{c}14.3 \\
(9.7,18.9)\end{array}$ \\
\hline $\begin{array}{l}\text { Q3 (How likely would you be willing to see a } \\
\text { Medical Doctor if you found out that you have } \\
\text { kidney problems?) }\end{array}$ & $\begin{array}{c}3.6 \\
(1.2,6.0)\end{array}$ & - & $\begin{array}{c}14.3 \\
(9.7,18.9)\end{array}$ & $\begin{array}{c}82.1 \\
(77.1,87.1)\end{array}$ \\
\hline
\end{tabular}

We also found that the scores of knowledge and attitude towards CKD were significantly associated with some sorts of socio-demographic factors of the respondents. Knowledge score has significantly differed with the sex $(p<0.001)$, level of education ( $p<0.001)$, occupation $(p<0.001)$, and monthly family income $(p<0.001)$. And, attitude score has significantly differed with the sex $(p=0.003)$, occupation $(p<0.001)$, and monthly family income $(p<0.001)$, details in Table 4. 
Table 4. Relationship between the socio-demographic factors and the scores of knowledge \& attitude towards chronic kidney disease among the diabetic population in a selected hospital in Dhaka city of Bangladesh $(n=224)$

\begin{tabular}{|c|c|c|}
\hline Characteristics & $\begin{array}{c}\text { Knowledge score } \\
\text { Mean } \pm \text { SD }\end{array}$ & Attitude score Mean $\pm S D$ \\
\hline \multicolumn{3}{|l|}{ Sex } \\
\hline Men & $5.4 \pm 2.3$ & $6.1 \pm 1.6$ \\
\hline Women & $3.7 \pm 2.0$ & $6.7 \pm 1.3$ \\
\hline$p$-value & $<0.001^{*}$ & $0.003^{*}$ \\
\hline \multicolumn{3}{|l|}{ Age (in years) } \\
\hline$<40$ & $4.0 \pm 2.1$ & $6.6 \pm 1.1$ \\
\hline $40-49$ & $4.3 \pm 2.6$ & $6.9 \pm 1.5$ \\
\hline $50-59$ & $4.4 \pm 1.8$ & $6.4 \pm 1.4$ \\
\hline$\leq 60$ & $4.1 \pm 2.6$ & $6.3 \pm 1.5$ \\
\hline$p$-value & 0.760 & 0.202 \\
\hline \multicolumn{3}{|l|}{ Level of education } \\
\hline Illiterate & $2.7 \pm 2.4$ & $6.8 \pm 1.1$ \\
\hline Primary school pass & $4.3 \pm 1.5$ & $6.6 \pm 1.3$ \\
\hline Secondary school pass & $4.0 \pm 2.2$ & $6.4 \pm 1.5$ \\
\hline Higher secondary school pass & $5.3 \pm 2.4$ & $6.3 \pm 1.7$ \\
\hline Graduation and more & $5.2 \pm 1.8$ & $6.7 \pm 1.6$ \\
\hline$p$-value & $<0.001^{\star}$ & 0.512 \\
\hline \multicolumn{3}{|l|}{ Occupation } \\
\hline Employee & $5.6 \pm 1.9$ & $5.4 \pm 1.7$ \\
\hline Business & $5.4 \pm 2.2$ & $6.6 \pm 1.4$ \\
\hline Day labor/farmer & $7.0 \pm 0.0$ & $5.0 \pm 0.0$ \\
\hline Housewife & $3.5 \pm 2.0$ & $6.9 \pm 1.2$ \\
\hline Others & $5.2 \pm 2.7$ & $6.3 \pm 1.7$ \\
\hline$p$-value & $<0.001 *$ & $<0.001 *$ \\
\hline \multicolumn{3}{|l|}{ Monthly family income (in BDT) } \\
\hline$<30,000$ & $4.0 \pm 2.2$ & $6.7 \pm 1.1$ \\
\hline $30,000-50,000$ & $4.4 \pm 2.2$ & $6.4 \pm 1.7$ \\
\hline$>50,000$ & $7.5 \pm 1.6$ & $4.5 \pm 1.6$ \\
\hline$p$-value & $<0.001 *$ & $<0.001 *$ \\
\hline \multicolumn{3}{|l|}{ Area of living } \\
\hline Urban & $4.3 \pm 2.4$ & $6.5 \pm 1.5$ \\
\hline Rural & $3.7 \pm 1.7$ & $6.7 \pm 1.1$ \\
\hline$p$-value & 0.113 & 0.250 \\
\hline
\end{tabular}


Figure 1. Bland-Altman Plot illustrating the agreement between knowledge and attitude domain scores. The difference between knowledge and attitude domain scores is shown against the mean knowledge-attitude score. Mean difference $=-2.32(S D=3.23), 95 \%$ limits of agreement $=-8.64: 4.00$

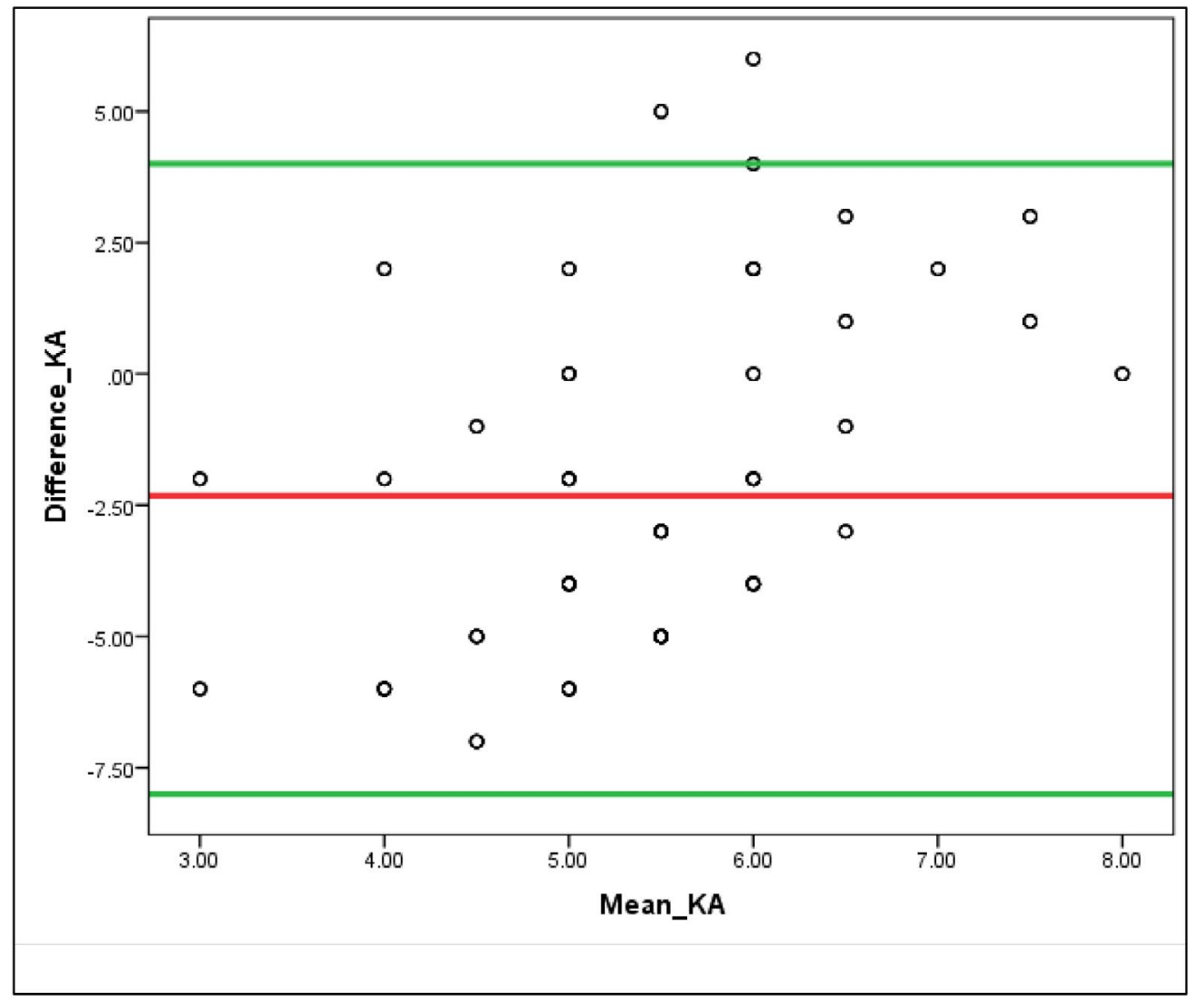

\section{Discussion}

The current study is probably the first-ever study in Bangladesh in which the level of KAP towards CKD among the T2DM without known CKD patients was uncovered. This study will help the policymakers understand the importance of appropriate programming strategies to increase awareness about CKD among the high-risk population. Implementing proper actions will help prevent CKD among them to reduce the disease burden in Bangladesh, such a low-resourced developing country.

We found most of our study population with an average level of knowledge and attitude. Moreover, most of them reported good practice in general for the hypothetical practice domain. We found a relatively lower level of knowledge from our study population compared to the Jordanian DM patients (mean \pm SD percentage $42 \pm 23$ vs. $80.24 \pm 10.4$ ), although the level of attitude was similar (mean \pm SD percentage $81.3 \pm 17.5$ vs. $78.7 \pm 8.1$ ). The lower level of knowledge among our study population probably is due to the lower age, noticeable illiterate population, and a disproportionate men-women ratio. In contrast, we had a higher proportion of women who had significantly $(p<0.001)$ lower knowledge scores than the men compared to the Jordanian study. ${ }^{11}$ Compared to men, the lower knowledge score possessed by the women in our study might be due to reflection of comparatively lower age (47.6 \pm 11.0 vs. $54.9 \pm 10.4$ years), low level of education (such as graduation and above $15.4 \%$ vs. $35.3 \%$ ), mostly housewives and less engagement in the income-generating professions as well as less income (not shown in table). However, our study population possessed a higher level of knowledge than Australian T2DM patients with other diseases (average of 20\%). ${ }^{12}$ We also found our study population had a remarkably higher level of knowledge and attitude than the Ethiopian T2DM and/or hypertension with CKD patients (63.5\% with poor knowledge and $41.3 \%$ with a positive attitude). ${ }^{13}$ The higher level of knowledge and attitude in our study population might be due to the higher age, more educated and higher proportion from urban residence than both studies. ${ }^{12-13}$ It most importantly might be due to the usage of asymmetric and distinctive knowledge and attitude assessing tools in these studies. 
There is no relevant national study focusing KAP towards CKD among DM patients to justify the findings of our study. However, awareness about CKD was assessed in a survey conducted among general patients without CKD attending the medicine department of a tertiary level hospital in Dhaka city. And, the majority (60\%) of them were reported with low knowledge, indicating a higher level of knowledge in our study population than them. ${ }^{17}$ Most importantly, the variations in the level of KAP in our study are mostly due to the asymmetric knowledge assessing tools and methods of determining the level of KAP in the other studies. .11-13,17 $^{1}$

As part of epidemiological studies, our study has few issues related to weak points. A conveniently selected (nonrandomized) study center and study population of T2DM patients in our study may not represent the generalizability of whole T2DM patients. A small sample might also be an issue in the same regard, although our study sample size satisfied well compared to the estimated sample size $(n=184$, in $\mathrm{n}=\mathrm{z} 2 \mathrm{pq} / \mathrm{d} 2$ formula) using the $13.9 \%$ CKD prevalence among newly registered T2DM patients in a hospital9. We could not justify our study findings with any other national study as there was a lack of relevant studies. There was no uniform tool and method to determine the level of KAP towards CKD for uniform justification of the findings.

\section{Conclusion}

T2DM patients reported mostly the average level of knowledge and attitude and good hypothetical practices in general towards CKD. Proper health promotion and health education programs are needed to increase the level of knowledge and attitude towards CKD among T2DM patients in Bangladesh. Further large-scale studies are needed to insight the issue more clearly.

\section{Acknowledgements}

We thank all participants of the study. We would also like to acknowledge the authority of Aalok Healthcare Ltd. (branch no. 2). There is no support with translating or editing by third parties such as professional commercial writing/editing services.

\section{Authors 'contributions}

Mondal $\mathrm{R}$ participated in the conception, design of the article, interpretation, data analysis, writing, critical review, and editing. Ritu RB participated in the collection, analysis, and interpretation of the data. Rahman MS and Sarker RC participated in the interpretation of the data. Banik PC participated in the writing, critical review, and editing. All authors read and approved the final manuscript.

\section{Competing interests}

No financial, legal, or political competing interests with third parties (government, commercial, private foundation, etc.) were disclosed for any aspect of the submitted work (including but not limited to grants, data monitoring board, study design, manuscript preparation, statistical analysis, etc.).

\section{References}

1. Luyckx VA, Tonelli M, Stanifer JW. The global burden of kidney disease and the sustainable development goals. Bulletin of the World Health Organization. 2018;96:414-422D. https://dx.doi. org/10.2471/BLT.17.206441

2. Jha V, Garcia-Garcia G, Iseki K, Li Z, Naicker S, Plattner B, et al. Chronic kidney disease: global dimension and perspectives. Lancet. 2013;382(9888):260-72. https://doi.org/10.1016/s0140$\underline{6736(13) 60687-x}$

3. Hill NR, Fatoba ST, Oke JL, Hirst JA, O'Callaghan CA, Lasserson DS, et al. Global Prevalence of Chronic Kidney Disease - A Systematic Review and Meta-Analysis. PLoS One. 2016;11(7):e0158765. https://doi.org/10.1371/journal. pone. 0158765

4. Hasan MJ, Kashem MA, Rahman MH, Qudduhush R, Rahman M, Sharmeen A, et al. Prevalence of chronic kidney disease (CKD) and identification of associated risk factors among rural population by mass screening. CBMJ. 2012;1(1):20-6. https://doi.org/10.3329/ cbmj.v1i1.13825

5. Anand S, Khanam MA, Saquib J, Saquib N, Ahmed T, Alam DS, et al. High prevalence of chronic kidney disease in a community survey of urban Bangladeshis: a cross-sectional study. Global Health. 2014;10:9. https://doi.org/10.1186/1744-8603-10-9

6. National Kidney Foundation. Diabetes and chronic kidney disease [Internet]. New York: National Kidney Foundation; 2016. Available from: https://www.kidney.org/news/newsroom/ factsheets/Diabetes-And-CKD

7. Shen Y, Cai R, Sun J, Dong X, Huang R, Tian S, et al. Diabetes mellitus as a risk factor for incident chronic kidney disease and end-stage renal disease in women compared with men: a systematic review and meta-analysis. Endocrine. 2017;55(1):66-76. https://doi.org/10.1007/s12020-016-1014-6 
8. Rahim MA, Mitra P, Haque HF, Samdani TS, Zaman S, Uddin KN. Prevalence of chronic kidney disease stages 3-5 among patients with type 2 diabetes mellitus in Bangladesh. IMC J. Med. Sci. 2017;11(1):19-24. http://dx.doi.org/10.3329/imcjms.v11i1.31934

9. Khanam PA, Sayeed MA, Islam A, Begum T, Habib SH, Nahar N, et al. Hospital-based prevalence of chronic kidney disease among the newly registered patients with diabetes. J Diabetol [Internet]. 2016;7(3):2. Available from: https://www. researchgate.net/profile/Parvin-Khanam/publication/309805649 Hospital-based_prevalence_of_chronic_kidney_disease among_the_newly_registered_patients_with_diabetes/ links/582425a008ae61258e3cdfaf/Hospital-based-prevalenceof-chronic-kidney-disease-among-the-newly-registered-patientswith-diabetes.pdf

10. Zibran MA, Mohammadnezhad M, Page R, Khan S. Knowledge, attitude and practice of type 2 diabetic patients with chronic kidney disease: a literature review. ARC j. public health community med. 2018;3(2):19-27. https://dx.doi.org/10.20431/24560596.0302004

11. Khalil A, Abdalrahim M. Knowledge, attitudes, and practices towards prevention and early detection of chronic kidney disease. Int Nurs Rev. 2014;61(2):237-45. https://doi.org/10.1111/inr.12085

12. White SL, Polkinghorne KR, Cass A, Shaw J, Atkins RC, Chadban SJ. Limited knowledge of kidney disease in a survey of AusDiab study participants. Med J Aust. 2008;188(4):204-8. https://doi. org/10.5694/j.1326-5377.2008.tb01585.x
13. Goro KK, Wolide AD, Dibaba FK, Fufa FG, Garedow AW, Tufa $\mathrm{BE}$, et al. Patient awareness, prevalence, and risk factors of chronic kidney disease among diabetes mellitus and hypertensive patients at Jimma University Medical Center, Ethiopia. Biomed Res. Int. 2019:2383508. https://doi.org/10.1155/2019/2383508

14. The World Bank. Population, total - Bangladesh [Internet]. World Bank Group; 2019. [cited 2020 May 27]. Available from https://data.worldbank.org/indicator/SP.POP.TOTL?locations=BD

15. Akter S, Rahman MM, Abe SK, Sultana P. Prevalence of diabetes and prediabetes and their risk factors among Bangladeshi adults: a nationwide survey. Bull World Health Organ. 2014;92(3):204-13, 213A. https://dx.doi. org/10.2471\%2FBLT.13.128371

16. Stanifer JW, Karia F, Voils Cl, Turner EL, Maro V, Shimbi $D$, et al. Development and validation of a cross-cultural knowledge, attitudes, and practices survey instrument for chronic kidney disease in a Swahili-speaking population. PLoS ONE. 2015;10(3):e0121722. https://doi.org/10.1371/journal. pone. 0121722

17. Jahan F, Rahman AKMS, Mahbub T, Noman MU, Akter Y, Rahaman MM, et al. Awareness of chronic kidney disease among patients attending tertiary care hospital in Bangladesh. J Biosci Med [Internet]. 2019;7:106-18. https://m.scirp.org/papers/94763 